\title{
Code-switching in tertiary-level EFL classrooms: perceptions of teachers
}

\author{
Ilknur Istifci a *
}

\section{APA Citation:}

${ }^{a}$ Anadolu University, The School of Foreign Languages, Eskisehir 26555, Turkey

Istifci, I. (2019). Code-switching in tertiary level EFL classrooms: perceptions of teachers. Journal of Language and Linguistic Studies, 15(4), 1287-1299.

Submission Date:07/08/2019

Acceptance Date:18/12/2019

\begin{abstract}
This study aims at examining the functions of 4 teachers' and their students' code-switching in tertiary-level EFL classrooms and the teachers' perceptions of code-switching. Data were collected by video-recording of the lessons of each teacher once a week and the classes were video-recorded in a three-week period. After transcribing video recordings of their lessons, the data were analysed qualitatively by finding the code-switching functions of teachers and students and finding if there are any similarities and differences between novice and experienced teachers' code-switching functions. Moreover, semi-structured interviews were also carried out with the teachers to get their perceptions of code-switching. Results of the study showed that teachers did not use code-switching most of the time in teaching, there were a few instances. Of these instances, some similarities and differences among teachers' and students' functions of code-switching, and also between novice and experienced teachers' use of codeswitching in classroom discourse were detected. Furthermore, interviews revealed that what the teachers do in the classroom in terms of code-switching and their perceptions on code-switching matched. Based on the results, some implications were mentioned in terms of the use of L1 in language classes.
\end{abstract}

(C) 2019 JLLS and the Authors - Published by JLLS.

Keywords: EFL teaching; classroom interaction; code-switching; code-switching functions

\section{Introduction}

Nowadays, there is a growing trend to learn new languages and the contact of people speaking different languages has been a common issue. Thus, code-switching can be observed in bilingual, multilingual and multicultural communities especially in language classrooms by the teachers and the students with different functions (Chung, 2006). Cantone (2007) states that code-switching has a significant place in bilingual research that tries to illuminate the concept of bilingualism.

Lin (2008) defines classroom code-switching as the use of more than one linguistic code alternatively in the classroom by the teacher and students. According to Martin $(2005, \mathrm{p} .89)$ "codeswitching offers classroom participants creative, pragmatic, and safe practices ... between the target language and the native language of classroom participants." According to Losey (2009), classroom code-switching research provides an understanding of the discourse of a shared identity and community among the participants.

\footnotetext{
* Corresponding author. Tel.: +90 (222) 33505 80/6111

E-mail address: iistifci@ anadolu.edu.tr
} 
The use of L1 is a widely observed phenomenon in English language classrooms and it dates back to the period when the Grammar Translation Method (GTM) was used intensively. In GTM, translation was seen as the best way to teach English with the help of L1. However, the Direct Method banned the use of L1 in English language classrooms and this ban lasted for 120 years (Cook, 2001). In Communicative Language Teaching Method, the use of L1 was accepted to a certain extent. For Iyitoglu (2016), it is important to have an insight of the functions of switching between L1 and foreign language and the reasons of code-switching. Thus, this will raise language teachers' awareness of L2 use in the classroom discourse, and "will lead to better instruction by either eliminating it or dominating its use during the foreign language teaching" (Sert, 2005, p.1).

\subsection{Literature review}

Code-switching is defined as "a phenomenon of switching from one language to another in the same discourse" (Nunan \& Carter, 2001, p.275). For Gardner-Chloros (2009) and Levine (2011), it is "the systematic alternate use of two or more languages in a single utterance or conversational exchange for communicative purposes." Code switching (CS) is observed in teachers' and students' discourse in language classrooms. As Iyitoglu (2015) states, teachers do not code-switch consciously. Supporting this view, Sert (2005) questions whether the teachers are aware of the functions and outcomes of the code-switching process or not.

"Teachers' code-switching has been up for debate since it is sometimes performed subconsciously and automatically (Modupeola, 2013, p.93) rather than as an intentional teaching strategy." As Sert (2005) states, code-switching in language classroom does not block learning a language, but can be considered as a useful strategy in classroom discourse when the aim of the teacher is to clarify the meaning and help students comprehend the topic efficiently. He warns that when the students interact with the native speakers of the target language, it can be a barrier which prevents intelligibility in the long term. "The teacher has an important role for preventing its long-term damages on foreign language learning process" (Sert, 2005, p.5). For Liu et al. (2004), there are two major views in the use of code switching: one opposes code switching to L1 and favors using only L2 in classroom and the other supports code switching and favors using L1 to some extent in the classroom.

As Sert (2005, p.4) states, "teachers who prefer to use the communicative techniques in language teaching, oppose any form of native language use during classroom instruction". Similarly, (Turnbull \& Arnett, 2002, p. 206) claim that "teacher's use of the target language should be maximized in the classroom and this is a reasonable practice because the teachers are often the students' main source of linguistic input on the target language."

However, some researchers claim that switching to L1 may have some benefits (Gabrielatos, 2001; Levine, 2011; Cook, 2001; van Lier, 1995; Macaro, 2001, 2005) and careful and limited use of the L1 should be employed (Gabrielatos, 2001). In accordance with this claim, Cook (2012) believes that code switching is natural in a language classroom and teachers should not discourage students from using it. He argues that "the maximization of L2 in the classroom does not mean that the L1 should be avoided altogether" (Bilgin, 2016, p.688). Macaro (2001, p.535) claims that using L1 may save time instead of using only the target language. In a similar vein, van Lier (1995) claims that students' L1 uses may be encouraged in order to provide more remarkable input for the learner. For Levine (2011), there are two or more languages involved in the L2 learning process since the language classroom is multilingual, and this fact should be taken into account in order to examine language classroom communication. Similarly, Kirkpatrick (2014, p.218) claims that "code-switching is an inevitable way of communication among bilinguals; thus, only using only one language is unnatural in a multilingual classroom". Furthermore, 
as Setati et al. (2002) state, code-switching may support communication and students' speech attempts in order to learn in the classroom.

In terms of the functions of code switching, there have been many studies conducted in bilingual, multilingual, ESL or EFL contexts (e.g., Sert, 2005; Iyitoglu, 2015; Greggio \& Gil, 2007; Raman \& Yigitoglu, 2018; Rukh, Saleem, Javeed \& Mehmood, 2014; Zabrodjkaja, 2007; Ferguson, 2003, 2009).

Ferguson $(2003,2009)$ put forward a framework for the pedagogical functions of classroom codeswitching which includes: "(1) code-switching for constructing and expressing knowledge access, for scaffolding knowledge, explantaion of key L2 technical terms and mediation of L2 textbooks; (2) codeswitching for classroom management, for indicating a shift, managing students' behavior such as: motivating, disciplining, and praising them; and (3) code-switching for interpersonal relations to create more humanistic classrooms" (Cahyani, Courcy \& Barnett, 2018, p.467).

One of the functions of teachers' code-switching is facilitating understanding of grammatical structures and rules. It explains "a situation where a teacher changes his/her language according to the topic under discussion" (Iyitoglu, 2015, p.261). Sert (2005) points out that the teacher changes his/her language to the students' native language in dealing with certain grammar points taught at that moment. Carrying out a study among Portuguese speaking university students who were learning English, Greggio and Gil (2007) stated that the teacher switched codes from L2 to L1 to clarify understanding of grammatical structure and led the learners to reflect on the form under analysis and facilitated its understanding. Bergsleithner (2002) found that the learners used code switching to express themselves better and code switching is employed for understanding the grammar topics.

Another function of teachers' code-switching can be found in creating a supportive language environment in the classroom and maintaining discipline. As Sert (2005) states, the teacher changes codes to build intimate relations with the students. Zabrodjkaja (2007) found out that the teacher shifted to L1 to praise or tell off a student. Carrying out a study on beginner-level EFL learners, Braga (2000) found out that code switching was used to create a more comfortable atmosphere in the EFL classroom by using humor.

Teachers also employ code-switching to repeat what they say in L2 to clarify the meaning. For Cipriani (2001), code switching fostered oral participation among the teacher and learner, and it is used to make the meaning of vocabulary clear, give instruction in carrying out tasks and to encourage learners to speak in English. However, Sert $(2005$, p.3) warns that "this tendency to repeat the instruction in L1 may cause the learners lose their motivation to listen to the instruction in L2."

The last function of code-switching is for establishing effective communication. For Iyitoglu (2015), most of the time, it is the teaching method which should be adjusted and not the language of instruction, and the most crucial question is how appropriately L1 is used and how it can be used to foster learning of $\mathrm{L} 2$.

Like the teachers, students may not be aware of the reasons for code-switching in the classroom. One of the functions of students' code-switching is equivalence when students use the native equivalent of a word to continue the communication. For Sert (2005, p.3), "this process may end up with the deficiency in linguistic competence of the target language, which makes the student use the word in his/her native language instead of the target language item."

The second function is reiteration in which "messages are reinforced, emphasized, or clarified where the message has already been transmitted, but not understood" (Eldridge, 1996, p.306). In this case, "the student repeats the message in the native language instead of using the target language so the learner tries to express the meaning by making repetition" (Sert, 2005, p.4). 
The next function is floor-holding. As Sert (2005) states, during a conversation, students fill the gap with native language use in order to close gaps in communication. He adds that this type of learners generally cannot remember the appropriate target language structure or lexicon.

The fourth function of students' code-switching is conflict control. For Sert (2005), students codeswitch in order to express the intended meaning according to their needs, intentions or purposes. $\mathrm{He}$ adds that "if there are not some culturally equivalent lexis among the native language and target language, it may result in code switching for conflict control so, possible misunderstandings are avoided" (Sert, 2005, p.4).

In the light of the findings stated above, this case study aims at investigating the code-switching functions of 2 novice and 2 experienced teachers and their students. This study also aims at getting the perceptions of teachers on code-switching. As this study is carried out in an intensive language teaching program of a state university, it aims to shed light on the use of code-switching by the teachers and intermediate-level students in terms of its functions. Moreover, this study aims at making teachers who are teaching in intermediate levels be aware of the use of code-switching in the classroom.

\subsection{Research questions}

By keeping the aims mentioned above in mind, this study tried to answer 3 research questions:

1. What are the functions of code switching of novice and experienced teachers, and students?

2. Are there any similarities and differences between novice and experienced teachers' use of code switching, and their students' code switching?

3. What are the teachers' beliefs on code switching?

\section{Method}

\subsection{Research design}

This qualitative case study aimed to get insights on 4 teachers' and their intermediate-level students' code-switching functions in 4 different classrooms. The study was limited to 4 teachers although there were about 20 classes and 35 teachers teaching English in the intermediate level classes in the prep school, so the results of this study cannot be generalized. The study focused on intermediatelevel learners and their teachers because it was hypothesized that the teachers and the students would not use code-switching a lot during the lessons in the classroom.

\subsection{Participants}

2 novice and 2 experienced teachers who are teaching in intensive language teaching program at the School of Foreign Languages in a state university participated in the study. They were chosen on a voluntary basis among the teachers teaching in intermediate level classes. In choosing the teachers, as novice and experienced, their ages were not taken into consideration. The number of years they were teaching English was taken into consideration. The information about the teachers can be seen in Table 1.

95 intermediate level students who are learning English in intensive language teaching program at the same school also participated in the study. Their ages ranged from 18 to 24 . Both the teachers and the students signed consent forms to be video-recorded three times. 
Table 1. Demographic information of teachers

\begin{tabular}{ccccc}
\hline Teachers & $\begin{array}{c}\text { Novice Teacher } \\
\text { A }\end{array}$ & $\begin{array}{c}\text { Novice Teacher } \\
\text { B }\end{array}$ & $\begin{array}{c}\text { Experienced } \\
\text { Teacher A }\end{array}$ & $\begin{array}{c}\text { Experienced } \\
\text { Teacher A }\end{array}$ \\
\hline Variables & Male & Female & Male & Female \\
Gender & 29 & 31 & 57 & 45 \\
Age & CELTA & MA in ELT & MA in ELT & MA in TEFL \\
$\begin{array}{c}\text { Degree or } \\
\text { Certificate } \\
\text { Major }\end{array}$ & ELT & ELT & ELT & ELT \\
$\begin{array}{c}\text { Teaching } \\
\text { experience }\end{array}$ & 5 years & 8 years & 22 years & 21 years \\
\hline
\end{tabular}

\subsection{Data collection procedures}

The participating teachers were video recorded once a week over a period of three weeks in their own classrooms. The cameras were placed at the back of the classroom before the lessons and the teachers started the recordings when they entered the classrooms. A lesson lasted for 45 minutes, so every teacher was recorded for 135 minutes. The time of the recordings was decided with the teachers and the researcher. The teachers were not informed about the focus of the recordings in order not to distract the flow of the lessons.

One week after the recordings, semi-structured interviews were also carried out with the participating teachers. The following questions were asked in the interviews.

1. What do you think about code-switching in class? Should L1 be avoided or used in the classroom?

2. When do you switch codes in the class?

3. Did you code-switch when your lesson was video-recorded? What was the function?

4. Do your students code-switch? If so, for what purpose?

The interviews were tape-recorded and then transcribed. Since there were only 4 teachers, the transcribed interviews were written verbatim.

\subsection{Data analysis}

Video recordings of the lessons (a total of five hundred and forty minutes) were watched by the researcher and another teacher. Code-switching instances were detected, noted and the categories on the functions of teachers' and students' code-switching were detected. The categories were categorized according to Sert's (2005) classification. Taped-recorded interviews were transcribed and they were written verbatim.

\section{Results}

The first research question aimed to detect the functions of code-switching of teachers and students. Both novice teachers and experienced teachers were found to speak English most of the time in their teaching. There were a few instances of code-switching in their teaching. Novice teacher A codeswitched 10 times and Novice Teacher B code-switched 6 times. As there were not many code-switching instances, their numbers were not given. 
Table 2. Novice teachers' functions of code switching

\begin{tabular}{ccc}
\hline Function & Novice Teacher A & Novice Teacher B \\
\hline Grammar explanation & $\sqrt{ }$ & $\sqrt{ }$ \\
Vocabulary explanation & $\sqrt{ }$ & \\
Repetition for clarification & $\sqrt{ }$ & \\
Giving instruction & $\sqrt{ }$ & \\
Creating a supportive & $\sqrt{ }$ \\
language environment & & \\
\hline
\end{tabular}

Novice Teacher A was found to employ code-switching in explaining grammar, vocabulary, giving instructions, repetition for clarification and creating a supportive language environment by using jokes whereas Novice Teacher B did code-switching in vocabulary explanation.

Table 3. Students' functions of code switching

\begin{tabular}{ccc}
\hline Function & Novice Teacher A's students & Novice Teacher B's students \\
\hline Clarifying grammatical structures & $\sqrt{ }$ & $\sqrt{ }$ \\
Repetition & $\sqrt{ }$ & $\sqrt{ }$ \\
Showing personal attitude & & $\sqrt{ }$ \\
\hline
\end{tabular}

Their students used code switching in clarifying grammatical structures, maintaining flow of communication and showing personal attitude. Although Novice Teacher B spoke English most of the time in class, her students had tendency to speak Turkish in doing activities especially during pair and group work activities.

Table 4. Experienced teachers' functions of code switching

\begin{tabular}{ccc}
\hline Function & Experienced Teacher A & Experienced Teacher B \\
\hline Grammar explanation & $\sqrt{ }$ & \\
Vocabulary explanation & $\sqrt{ }$ & \\
Repetition for clarification & $\sqrt{ }$ & \\
Giving instruction & $\sqrt{ }$ \\
\hline
\end{tabular}

Experienced teacher A code-switched 5 times and was found to employ code-switching in explaining grammar, vocabulary, giving instructions and repetition for clarification whereas Experienced Teacher B did not do any code-switching in the class during teaching.

Table 5. Students' functions of code switching

\begin{tabular}{ccc}
\hline Function & $\begin{array}{c}\text { Experienced Teacher A's } \\
\text { students }\end{array}$ & $\begin{array}{c}\text { Experienced Teacher B's } \\
\text { students }\end{array}$ \\
\hline Clarifying grammatical structures & $\sqrt{ }$ & $\sqrt{ }$ \\
Maintaining flow of communication & $\sqrt{ }$ & \\
Showing personal attitude & $\sqrt{ }$ & \\
\hline
\end{tabular}


Experienced Teacher A's students used code switching in clarifying grammatical structures, maintaining flow of communication and showing personal attitude whereas Experienced Teacher B's students only used code switching in maintaining the flow of communication.

The second research question aimed to investigate if there are any similarities and differences between novice and experienced teachers in terms code-switching functions. When the novice teachers and experienced teachers are compared, it was seen that Novice Teacher A and Experienced Teacher A code-switched in explaining grammar and vocabulary, giving instructions and clarifying for repetition, and Novice teacher A also tried to create a supportive language environment by using jokes. Novice Teacher B, on the other hand, only code-switched in vocabulary instruction. However, the videos showed that the students of Novice Teacher B were inclined to code-switch and speak their native language a lot in the class. Experienced Teacher B did not do any code-switching and her students only code-switched in maintaining the flow of communication. As it was told before, there were not many instances of code-switching at all.

\subsection{Responses of the teachers}

Responses of the teachers were harmonious with the video recordings of the lessons. In other words, their responses showed their attitude of code switching and video recordings supported their views.

Novice Teacher A's responses

1. In my opinion, code-switching can be useful especially when working with lower level groups. I think the use of L1 should be avoided as long as it can be avoided, but I don't see the use of L1 as something that "has to" be avoided. Knowing that using L1 is possible whenever it is really necessary makes both the teacher and students comfortable, especially with the lower level groups.

2. When and to what extent I switch codes or use L1 mostly depends on groups I am working with. With groups with high motivation, I mostly don't need to switch codes at all even when teaching grammar. With groups with low motivation, I usually need to (or I mistakenly assume I need to) switch codes more often.

3. I did, but since both of the groups mostly consist of students who have high motivation for learning English, I only used it to check understanding, which I believe is harmless in any case.

4. They do. They mostly do it when they ask for further clarification on a specific subject and they tend to avoid it whenever they can. I believe they feel safer knowing that they can go back to their own language when they "really" need to, and knowing that they will be understood when they do.

Novice Teacher B's responses

1. I think code-switching should not be considered as a taboo in language classes. Especially if students and the teacher speak the same language and come from similar backgrounds. In some cases, it can be considered as an advantage in teaching, too. However, the use of native language should be quite limited not to harm the nature of language learning. I don't think that in such a case L1 usage should be avoided. If I can benefit from my students' native language to teach them a word, a phrase or a simple structure better, I should alternate and make use of this. Making use of similar sounds, sayings or usages between two languages can be more helpful. L1 is like a small helping tool for me, and I don't see any need to strictly forbid it in my classes.

2. I mostly switch to explain a word or a phrase better. Also, I prefer giving examples when needed. For example, I say: "we have the same or similar thing in Turkish as ......" Referring to some jokes or common cultural things help students to better remember what I am telling.

3. As far as I can remember, I did a few times only. It was when I was teaching vocabulary. As I mentioned above, just giving the synonyms or explaining the word might not be helpful if I can't find enough time for vocabulary teaching as I wish. I attach importance to students' using the words 
correctly, and to realize this, there is needed extra time for activities which focus on target vocabulary.

4. Yes. To ask a question, mostly they prefer Turkish, but they do this like "Can I ask a question, but it's not related to the lesson." Sometimes during the lesson, when I ask a question, they start in English, but then they switch saying "Can I tell this in Turkish? It's a very nice story or I don't know how to say this in English. It's difficult." "What does .... mean in English?" When they can't find the word, they ask me and after learning the word they need, they go on in English.

\section{Experienced Teacher A's responses}

1. It is okay to use L1 for a short time to avoid long explanations, answer the students' questions asked in Turkish and make jokes.

2. When I see the students have a lot of questions in their minds but they hesitate to ask and when I am short of time and want to save some time.

3. I don't remember... but possible, sometimes when the students ask a question in Turkish, I usually answer it in Turkish.

4. Possible... when they want to ask a question, they generally prefer using L1 to ask their questions.

\section{Experienced Teacher B's responses}

1. I think code-switching can be practical in some cases. It sometimes enhances the teaching/learning process. Therefore, I don't think we should avoid it. However, it shouldn't dominate the class language.

2. When I think that it will save me time, I do it. For instance, if I see that explaining a new grammar item all in English will take too much time, I make use of my L1 in some parts.

* I sometimes switch codes to make my students feel relaxed (to lower their anxiety). I explain the topic in English, and then if I see to many question marks, I make use of L1 partly for repetition.

* I do it to fix the problems in pair work or group work activities. After giving the instruction, I walk in the classroom and if I see that some pairs/groups have misunderstood the activity. I repeat it in Turkish quickly.

3. I don't remember much, but I think I did it while answering individual questions during an activity.

4. They do. They tend to use L1 a lot. Basically, not because they can't ask a question in English, but because they are lazy to use L2. They are not motivated enough to do so although I have asked them to use L2 in class many times before.

\section{Discussion}

The video recordings of the lessons revealed that participating teachers did not code-switch most of the time in the lesson. They always spoke English so there were a few instances of code-switching. They mostly code-switched to explain grammar and vocabulary, to clarify and to give instruction. This finding is in accordance with Ferguson's (2003) classification of code switching that involves clarification or negotiation of meaning by using code-switching, and Levine's (2014) claim that code switching is used to explain grammatical items or to learn vocabulary.

The teachers in this study were also observed to code-switch according to their students' reactions. When they observed that their students did not react to their prompts, they code-switched deliberately (especially Novice Teacher A). Although Novice Teacher B did not do code-switching a lot, her students 
code-switched and used their L1 most of the time in the classroom. This may stem from the attitude of Novice Teacher B or they might not have understood the topic and needed some explanation in their native language. She spoke English with a soft voice in the class, she was so polite, she never shouted at her students in the class. However, her students spoke Turkish a lot during the lesson. Her students' tendency to speak in L1 may also stem from the class dynamics. As every class is unique, the students in this class had tendency to speak in their L1 since the teacher did not warn or shout at them.

Novice Teacher A also code-switched when he wanted to create a stress-free environment in the class by using some humor. This finding is in line with the studies of Cahyani et al. (2018) and Braga (2000). As Cahyani et al. (2018) state, code-switching for humorous purposes is a strategic skill that makes the classroom an enjoyable place for learning. In a similar vein, Braga (2000) points out that code-switching is a strategy that indicates humorous situations when correcting activities, so it contributes to create a more comfortable atmosphere in the EFL classroom.

As both the novice and the experienced teachers' responses reveal, they feel positive about codeswitching in class to facilitate students' understanding of vocabulary and grammar items. This finding is in line with the studies of Durano (2009) and Al-Nofaie (2010) who claim that code-switching is useful in teaching content and help teachers better clarify their task instruction, reduce students' stress, encourage them to talk about their feelings, attract students' attention and manage classes effectively. The teachers' responses also support Macaro's (2005) claim that L1 use is not only natural in L2 learning and teaching but also a more time saving strategy than using only the target language.

In terms of the beliefs of the teachers, the video recordings of the lessons and teachers' beliefs were harmonious except the beliefs of Novice Teacher A. In answering the third question in the interview, he said he only code-switched in checking understanding, but actually, he also code-switched in grammar and vocabulary instruction and giving instructions.

\section{Conclusions}

This study showed that although novice and experienced teachers feel positive about the use of codeswitching in the class, they did not do code-switching a lot in the observed classes. Furthermore, Experienced Teacher B did not use any code-switching. It may be related to the identity of the teacher who preferred to use English all the time in the class by maximizing the use of English and she may have wanted to be a role model for her students. Thus, code switching indicates individual teachers' characteristics and identity. The teachers in this study mostly preferred to use English in the class since they were working in a school where English is taught intensively. The teachers may have wanted to provide more English input for their students.

This study also showed that code-switching has a direct effect on teachers' decision-making process. When the teachers felt a need, they used L1 in order to facilitate understanding of grammar or vocabulary items. Teachers in this study believe that it is inevitable to code-switch in the class since it may facilitate understanding of some items instead of repeating the same things in English. However, they must be cautious to use the native language in the class as it may become a habit for the students. As Horasan (2014) states, code-switching can be employed in EFL classrooms because teachers' use of code-switching is for the development of the students in the learning process and should not be taken for granted.

Novice Teacher A's use of code-switching by using humor is observed to create a supportive language learning environment. Thus, his students were observed to feel very relaxed in the class and participated in the lesson more.

On the other hand, Novice Teacher B only code-switched in explaining vocabulary and her students were observed to speak Turkish most of the time in the class. Since she used English most of the time 
in the class, her students may not have understood some topics and tried to speak in their L1. She may not be aware of the purposes of using L1 in English classrooms. "If so, this can have important implications for instructor training and novice instructors may need to become aware of the different ways in which L1 can be used in L2 classrooms to facilitate learning" (Campa \& Nassaji, 2009, p.757).

The results of this study may be shared with the novice and the experienced teachers by making them watch the videos and they can be aware of their code-switching instances in the classroom and they may reflect on the purpose of using L1 and L2 in the classroom. Furthermore, novice teachers may be encouraged to write lesson plans and state the anticipated problems such as using L1 in the classroom. They can also carry out classroom observations to gain an understanding on what goes in the classrooms in terms of code-switching.

\section{Limitations and suggestions}

This study has some limitations in terms of generalizability. Firstly, it was carried out with 4 teachers who are teaching in 4 different intermediate level classes. In another study, more teachers teaching in different levels may be video-recorded and their code-switching functions may be compared. Secondly, the data of this study were analyzed qualitatively since there were not many teachers and many instances of code-switching. Studies with more classes may be carried out and data may be analyzed quantitatively. Moreover, the recordings were done in three weeks in this study. More longitudinal studies may be carried out in future. A final limitation is gaining only the perceptions of the participating teachers on code-switching. Further studies can be conducted by getting the perceptions of the students on using L1 in language learning classrooms.

\section{Acknowledgements}

This study was presented with the title "Code switching in EFL classrooms" in ILTERG Conference in Antalya on 8-10 April, 2019.

\section{References}

Bergsleithne, J. M. (2002). Grammar and interaction in the EFL classroom: a sociocultural study. 2002. Master Dissertation - Universidade Federal de Santa Catarina, Florianópolis.

Bilgin, S.S. (2016). Code switching in English language teaching (ELT) teaching practice in Turkey: Student teacher practices, beliefs and identity. Educational Research and Reviews, Vol. 11(8), pp. 686-702.

Braga, M.C.O. (2000). Humor in the EFL classroom: a sociointeractionist perspective. Master Dissertation - Universidade Federal de Santa Catarina, Florianópolis.

Cahyani, H., Courcy, M. \& Barnett, J. (2018). Teachers' code-switching in bilingual classrooms: exploring pedagogical and sociocultural functions, International Journal of Bilingual Education and Bilingualism, 21(4), 465-479, DOI: 10.1080/13670050.2016.1189509

Campa, J. C. \& Nassaji, H. (2009). The Amount, purpose, and reasons for using L1 in L2 classrooms. Foreign Language Annals, V.42, N.4.

Cantone, K. F. (2007). Code-switching in bilingual children. Dordrecht: Springer. 
Chung, H. H. (2006). Code switching as a communicative strategy: A case study of Korean-English bilinguals. Bilingual Research Journal, 30(2), 293-307.

Cipriani, F. (2001). Oral participation strategies in the foreign language classroom: an ethnographic account. Master Dissertation - Universidade Federal de Santa Catarina, Florianopolis.

Cook, V. (2001). Using the first language in the classroom. Canadian Modern Language Review, 57(3):402-423.

Cook, V.J. (2012). Multicompetence. In C. Chapelle (Ed.), The encyclopaedia of applied linguistics. Wiley-Blackwell.

Durano, F. (2009). Attitudes towards English and Fil-English code-switching amongst high school students in Ormoc City, Philippines. Unpublished Master's Thesis, Malmö University.

Eldridge, J. (1996). Code-switching in a Turkish secondary school. ELT Journal, 50(4), 303-311. http://dx.doi.org/10.1093/elt/50.4.303

Haifa Al-Nofaie (2010). The Attitudes of Teachers and Students towards Using Arabic in EFL classrooms in Saudi Public Schools- A Case Study. Novitas-ROYA, Jourlib Journal ISSN: 23339721, 64-95.

Gabrielatos C. (2001). LI use in ELT: Not a skeleton, but a bone of contention. Brihes. P 6.

Gardner-Chloros, P. (2009). Code-switching. Cambridge: Cambridge University Press.

Greggio, S., \& Gil, G. (2007). Teacher's and learner's use of code switching in the English as a foreign language classroom: A qualitative study. Linguagem \& Ensino, 10(2), 371-393.

Horasan, S. (2014). Code-switching in EFL classrooms and the perceptions of the students and teachers. Journal of Language and Linguistic Studies, 10(1), 31-45.

Iyitoglu, O. (2016). Code-Switching from L2 to L1 in EFL Classrooms. Croatian Journal of Education, Vol.18; No.1, pages: 257-289

Kirkpatrick, A. (2014). "Afterword.” In Code-switching in University English-medium Classes: Asian Perspectives, edited by R. Barnard and J. McLellan, 214-221. Bristol: Multilingual Matters.

Levine, G. S. (2011). Code Choice in the Language Classroom. Bristol: Multilingual Matters.

Lin, A. (2008a). "Code-Switching in the Classroom: Research Paradigms and Approaches." In Encyclopedia of Language and Education, edited by K. A. King and N. H. Hornberger, 273-286. Boston, MA: Springer US.

Lin, A. (2013b). “Classroom Code-Switching: Three Decades of Research.” Applied Linguistics Review, 4 (1): 195-218.

Liu D, Ahn G, Baek K, Han N (2004). South Korean High school English teacherse code switching: Questions and challenges in the drive for maximal use of English in teaching. TESOL Quarterly, 38(4):605-638.

Losey, K. M. (2009). "Written Code-Switching in the Classroom: Can Research Resolve the Tensions?” International Journal of Bilingual Education and Bilingualism, 12 (2): 213-230.

Macaro, E. (2001a). Analyzing student teacher's code switching in the foreign language classrooms: Theories and decision making. The Modern Language Journal, 85, 531-548. http://dx.doi.org/10.1111/0026-7902.00124 
Macaro E. (2005b). Code switching in the L2 classroom: A communication and learning strategy. In Llurda (ed) Non-Native Language Teachers: Perceptions, Challenges and Contributions to the Profession. Springer. pp. 63-84.

Martin, P. W. (2005). “'Safe” Language Practices in two Rural Schools in Malaysia: Tensions between Policy and Practice." In Decolonisation, Globalisation: Language-in-education Policy and Practice, edited by A. M. Lin and P. W. Martin, 74-97. Clevedon: Multilingual Matters.

Modupeola, O. R. (2013). "Code-switching as a Teaching Strategy: Implications for English Language Teaching and Learning in a Multilingual Society." Journal of Humanities and Social Science, 14 (3): 92-94.

Raman, Y. \& Yigitoglu, N. (2018). Justifying code switching through the lens of teacher identities: novice EFL teachers' perceptions. Qual Quant, 52:2079-2092 https://doi.org/10.1007/s11135-0170617-1.

Rukh, S., Saleem, N., Javeed, H. G. M., \& Mehmood, N. (2014). Students' Attitudes towards Teachers' Code-Mixing/Code-Switching to L1 and Its Influence on Their L2 Learning: A Case of Business Students in Sargodha. International Journal of Science and Research, 3(5), 1111-1116.

Setati, M., J. Adler, Y. Reed, and A. Bapoo (2002). "Incomplete Journeys: Code-switching and Other Language Practices in Mathematics, Science and English Language Classrooms in South Africa." Language and Education, 16 (2): 128-149.

Sert, O. (2005). The functions of code switching in ELT classrooms. The Internet TESL Journal, 11(8) /online/. Retrieved on 18 January 2008 from http://www.iteslj.org/Articles/ Sert-CodeSwitching. html.

Turnbull, M. \& Arnett, K. (2002). Teachers' uses of the target and first languages in second and foreign language classrooms. Annual Review of Applied Linguistics, V.22, p.204-218.

van Lier L (1995). The use of L1 in L2 classes. Babylonia 2:37-43.

Zabrodskaja, A. (2007). Russian-Estonian code switching in the university. Arizona Working Papers in SLA \& Teaching, 14(1), 123-139. 


\section{Üniversite düzeyinde İngilizcenin yabancı dil olarak öğretildiği sınıflarda diller arası geçiş yapma: öğretmenlerin görüşleri}

\section{$\ddot{O} \mathbf{z}$}

Bu çalışma üniversite düzeyinde İngilizcenin Yabancı Dil Olarak Öğretildiği sınıflarda derse giren 4 öğretim elemanı ve onların öğrencilerinin diller arası geçiş yapmalarını incelemeyi amaçlamaktadır. Çalışmanın verileri her öğretmenin sınıf etkileşimindeki söylemlerini haftada bir kere 3 hafta boyunca video kaydı yaparak toplanmıştır. Video kayıtları çözümlenmiştir. Veriler öğrenci ve öğretmenlerin diller arası geçiş yapma fonksiyonlarını bulmak üzere ve deneyimli ve deneyimsiz öğretim elemanları arasında diller arası geçiş yapma fonksiyonları arasında benzerlik ya da farklılıklar olup olmadığını bulmak üzere nicel olarak analiz edilmiştir. Ayrıca öğretmenlerin görüşlerini almak için yarı yapılandırılmış görüşmeler yapılmıştır. Çalışmanın sonuçları öğretim elemanları-öğrenciler ve deneyimli ve deneyimsiz öğretmenler arasında diller arası geçiş yapma fonksiyonları açısından benzerlik ve farklılıklar olduğunu ortaya çıkarmıştır. Sonuçlara dayanarak anadilin dil öğrenilen sınıflarda kullanımı ile ilgili bazı çıkarımlarda bulunulmuştur.

Anahtar sözcükler: İngilizcenin yabancı dil olarak öğretimi; sınıf içi iletişim; diller arası geçiş yapma; diller arası geçiş yapma fonksiyonları.

\section{AUTHOR BIODATA}

Dr. İlknur İstifçi holds both MA and Ph.D. degrees in English Language Teaching. She is currently working as an Associate Professor at the School of Foreign Languages and teaching at ELT Department of Education Faculty, Anadolu University. Her research interests include teacher training, discourse analysis, classroom research, speech acts, cross-cultural studies, teaching language skills, digital literacy, distance education and using ICTs in ELT. 